\title{
EVALUASI PEMBERIAN MAKANAN TAMBAHAN PEMULIHAN (PMT-P) PADA BALITA KURANG GIZI DI KABUPATEN TUBAN
}

\author{
EVALUATION OF FEEDING'S PROGRAMME TO THE MALNUTRITION \\ UNDER FIVE CHILDREN IN TUBAN DISTRICT
}

\section{Elya Sugianti}

\author{
Badan Penelitian dan Pengembangan Provinsi Jawa Timur \\ Jln. Gayung Kebonsari No. 56, Surabaya \\ e-mail: sugiantielya@gmail.com
}

Diterima : 28 Juli 2017; direvisi : 21 November 2017; disetujui : 30 November 2017

\begin{abstract}
ABSTRAK
Program PMT-P adalah salah satu program yang dilaksanakan pemerintah dalam penanganan masalah gizi pada balita kurang gizi khususnya pada keluarga miskin. Namuan, selama ini masih banyak kendala dalam pelaksanaannya. Tujuan dari penelitian ini adalah untuk mengevaluasi pelaksanaan program PMT-P berdasarkan segi input, proses dan output di Kabupaten Tuban. Informan dalam penelitian ini adalah kasie gizi dinas kesehatan, kepala puskesmas, tenaga pelaksana gizi, bidan desa, dan kader. Analisis data dilakukan secara deskriftif. Hasil penelitian menunjukkan bahwa dai segi input, SDM dan bahan PMT-P sudah memadai, namun petunjuk pelaksanaan, sarana prasarana, dan pendanaan masih kurang, dari segi proses, penyimpanan, pengangkutan dan pemantauan masih kurang, dari segi output, ketepatan umur sudah sesuai dan ada keefektifan program dalam kenaikan berat badan. Kesimpulan dalam penelitian ini adalah program PMT-P sudah efektif dalam meningkatkan berat badan balita sasaran walaupun masih terdapat kendala dalam pelaksanaan program.
\end{abstract}

Kata kunci:kurang gizi, keluarga miskin, program PMT-P, evaluasi

\begin{abstract}
Feeding's programme is one of the government's programs in handling nutritional problems for under-five children especially in poor families. However, there are many obstacles in the implementation. The purpose of this research is to evaluate of feeding's programme based on input, process and output in Tuban district. The informant of this research are head section of health departement, head of public health center, nutritionist, midwives, and cadres. Data analysis were used descriptive analysis. The results showed that based on input, human resources and materials feeding's programme is adequate, but the guidance of implementation, infrastructure, and funding is still lacking, based on process, storage, transportation and monitoring is still lacking, based on output, accuracy of age is appropriate and feeding's programme effective to weight gain malnutrition under five children. The conclusion of this research is feeding's programme has been effective in increasing weight of target under five malnutrition children although there are still obstacles in program implementation.
\end{abstract}

Keywords : malnutrition, poor family, feeding's programme, evaluation 


\section{PENDAHULUAN}

Hingga saat ini masalah gizi masih menjadi isu permasalahan global baik di negara maju maupun di negara berkembang seperti Indonesia. Terdapat lima masalah gizi di Indonesia yang masih terus diupayakan penyelesaiannya, yaitu Kurang Energi Protein (KEP), Kurang Vitamin A (KVA), Gangguan Akibat Kekurangan Gizi Yodium (GAKY), Anemia Defisiensi Besi, dan obesitas. KEP merupakan salah satu dari lima masalah gizi yang menjadi momok kelompok rentan seperti balita. Penurunan prevalensi KEP cenderung berfluktuatif.

Secara nasional, Riset Kesehatan Dasar (Riskesdas) menemukan adanya peningkatan prevalensi balita pendek dari 35,6\%(2010) menjadi 37,2\%(2013), prevalensi gizi buruk dari 4,9\%(2010) menjadi 5,7\%(2013), dan prevalensi gizi kurang dari 13\%(2010) menjadi 13,9\%(2013) (Kemenkes 2010; Kemenkes, 2013a). Sementara di Jawa Timur, prevalensi balita pendek cenderung stagnan dari tahun 2010 ke tahun 2013 sebesar 35,8\%, prevalensi gizi buruk meningkat tipis dari 4,8\%(2010) menjadi 4,9\%(2013), dan prevalensi gizi kurang meningkat dari 12,3\%(2010) menjadi 14,2\%(2013) (Kemenkes, 2010; Kemenkes, 2013a)

Undang-undang Kesehatan No. 36 Tahun 2009 pasal 141 telah mengamanatkan upaya perbaikan gizi masyarakat yang bertujuan untuk meningkatkan mutu gizi perseorangan dan masyarakat melalui: perbaikan pola konsumsi makanan yang sesuai dengan gizi seimbang; perbaikan perilaku sadar gizi, aktivitas fisik, dan kesehatan; peningkatan akses dan mutu pelayanan gizi yang sesuai dengan kemajuan ilmu dan teknologi; dan peningkatan sistem kewaspadaan pangan dan gizi.

Sebagai tindak lanjut dari Undangundang Kesehatan No. 36 Tahun 2009 terkait upaya perbaikan gizi masyarakat, pemerintah telah menetapkan upaya kesehatan prioritas dalam pelayanan gizi, yaitu melalui upaya penurunan prevalensi gizi kurang dan gizi buruk. Salah satunya melalui program Pemberian Makanan Tambahan Pemulihan (PMT-P) terutama kepada balita dari keluarga miskin yang mengalami kekurangan gizi. Program PMT-P dimaksudkan untuk memenuhi kecukupan gizi balita dengan memberikan makanan tambahan untuk balita, dan bukan untuk mengganti makanan utama sehari-hari balita (Depkes, 2011). Beberapa penelitian terdahulu, telah menemukan adanya manfaat dari terselenggaranya program PMT-P, berupa penambahan berat badan dan status gizi balita setelah menerima program PMT-P (Rochyani dkk 2007; Supadmi dkk 2008; Sulistyaningsih 2013).

Pelaksanaan program PMT-P tak terlepas dari beberapa kendala. Adiyasa dkk (2010), menemukan banyaknya kendala dalam pelaksanaan program PMT-P, diantaranya masalah pendataan riil balita pada keluarga miskin, terbatasnya pengalokasian bahan dari pusat, sulitnya pemantauan petugas dalam ketepatan konsumsi pada sasaran, adanya penolakan PMT-P, adanya keterlambatan formulir pencatatan dan pelaporan, dan pelaksanaan program yang selalu di akhir tahun. Selain itu, menurut Lubis $d k k$ (2012), adanya sumber daya yang kurang, sarana dan prasarana yang minim, pendistribusian yang tidak sesuai sasaran, pemantauan status gizi balita yang belum sesuai standar juga merupakan kendala dalam pelaksanaan program PMT-P.

Berdasarkan hasil Riset Kesehatan Dasar, prevalensi kurang gizi di Kabupaten Tuban mengalami sedikit penurunan dari 18.7\% (2007) menjadi $17.4 \%$ (2013). Demikian halnya dengan prevalensi balita kurus (wasting), juga mengalami sedikit penurunan dari $16.7 \%$ (2007) menjadi $14.1 \%(2013)$. Sementara untuk prevalensi balita pendek (stunting) cenderung stagnan (37.7\% (2007) ke 37.7\% (2013) (Kemenkes 2008b; Kemenkes 2013b). Lain dari itu, berdasarkan data dari Dinas Kesehatan Provinsi Jawa Timur, prevalensi kurang gizi di Kabupaten Tuban pada tahun 2014 sebesar 16.2\%. Prevalensi ini sedikit lebih rendah dibandingkan dengan data dari Riskesdas. Sementara untuk prevalensi balita pendek, pada tahun 2014 sebesar 36.6\% di Kabupaten Tuban (Dinkesprov Jatim, 2015)

Mengingat masih tingginya prevalensi kurang gizi di Kabupaten Tuban serta masih banyaknya kendala dalam pelaksanaan program PMT-P, maka dipandang perlu untuk dilakukan evaluasi terhadap pelaksanaan program PMT-P pada balita keluarga miskin di Kabupaten Tuban. 


\section{Rumusan Masalah}

Berdasarkan latar belakang permasalahan yang telah dipaparkan dalam bahasan sebelumnya, dapat dirumuskan permasalahan "Bagaimanakah evaluasi pelaksanaan program PMT-P pada balita keluarga miskin dari segi input, proses dan output?"

\section{Tujuan Penelitian}

Tujuan dari penelitian ini adalah untuk mengevaluasi pelaksanaan program PMT-P pada keluarga miskin dari segi input, proses, dan output di Kabupaten Tuban.

\section{METODE}

Penelitian ini merupakan penelitian kualitatif yang bersifat deskriftif evaluatif. Penelitian dilakukan di empat puskesmas terpilih di Kabupaten Tuban. Jangka waktu penelitian selama dua bulan (Mei-Juni 2015). Teknik pengambilan informan menggunakan metode purposive. Informan dalam penelitian ini berjumlah 21 orang yang terdiri atas kasie gizi dinas kesehatan, kepala puskesmas, tenaga pelaksana gizi, bidan desa, dan kader. Data dibagi menjadi dua, yaitu primer dan sekunder. Data primer dikumpulkan dengan wawancara mendalam. Sementara data sekunder dikumpulkan dengan mendokumentasikan data-data terkait yang ada di dinas kesehatan dan puskesmas. Analisis data dilakukan secara deskriftif.

\section{HASIL DAN PEMBAHASAN}

\section{Aspek Input}

\section{Sumber daya manusia}

Sumber daya manusia (SDM) sangat penting peranannya dalam pelaksanaan program PMT-P. SDM yang bertanggung jawab terhadap pelaksanaan program PMT-P adalah kasie/staf gizi dinas kesehatan, kepala puskemas, tenaga pelaksana gizi puskesmas, dan bidan desa. Kualitas dan kuantitas SDM dapat dilihat berdasarkan latar belakang pendidikan yang sesuai dengan bidang pekerjaan dan lama kerja. Berdasarkan Tabel 1 pada sebaran umur, dapat dilihat bahwa semua informan yang bertanggung jawab sebagai pelaksana program PMT-P sudah berumur lebih dari 35 tahun. Sementara untuk sebaran latar belakang pendidikan, semua informan sudah memiliki latar belakang pendidikan yang sesuai dengan bidang pekerjaannya. Sedangkan untuk lama kerja, rata-rata informan sudah bekerja antara 10-20 tahun. Berdasarkan latar belakang pendidikan yang dimiliki dan lama kerja di dinas/puskesmas, dapat dijustifikasi bahwa dari segi kualitas dan kuantitas SDM yang bertanggung jawab terhadap program PMT-P di Kabupaten Tuban sudah cukup memadai.

Tabel 1. Sebaran SDM yang bertanggung jawab pada program PMT berdasarkan latar belakang pendidikan dan lama kerja

\begin{tabular}{lcccc}
\hline Kategori & $\begin{array}{c}\text { Kasie } \\
\text { dinkes } \\
\mathrm{n}=1\end{array}$ & $\begin{array}{c}\text { Kepala } \\
\text { puskesmas } \\
\mathrm{n}=4\end{array}$ & $\begin{array}{c}\text { Petugas } \\
\text { gizi } \\
\mathrm{n}=4\end{array}$ & $\begin{array}{c}\text { Bidan } \\
\mathrm{n}=4\end{array}$ \\
\hline Umur & - & - & - & - \\
& 1 & 4 & 4 & 4 \\
\hline Pendidikan & & & & \\
D3 bidan & - & - & - & 1 \\
D4 bidan & - & - & - & 3 \\
D3 gizi & - & - & 4 & - \\
D4 gizi & 1 & - & - & - \\
S1 kedokteran & - & 2 & - & - \\
S2 & - & 2 & - & - \\
\hline Lama Kerja & & & & \\
S10 tahun & - & - & - & - \\
10-20 tahun & 1 & 3 & 3 & 1 \\
$>$ 20 tahun & - & 1 & 1 & 3 \\
\hline
\end{tabular}

\section{Petunjukpelaksanaan}

Petunjuk pelaksanaan program PMT-P merupakan hal penting yang harus ada supaya program PMT-P dapat berjalan sebagaimana seharusnya. Petunjuk pelaksanaan dapat berupa buku pedoman, juklak atau juknis pelaksanaan program PMT-P. Hal ini penting supaya ada standar yang sama dalam pelaksanaan program PMT-P antara pihak dinas kesehatan sebagai koordinator program dan pihak puskesmas sebagai pelaksana program. Petunjuk pelaksanaan dalam program PMT-P belum terdistribusikan dengan baik karena masih adanya ketidaksamaan pendapat antara dinas kesehatan dan petugas pelaksana gizi puskesmas. Belum terdapatnya buku pedoman/juklak/juknis dalam program PMT-P di puskesmas akan dapat berimplikasi terhadap pelaksanaan program PMT-P.

\section{Sarana Prasarana}

Sarana prasarana yang terkait dengan pelaksanaan program PMT-P adalah keberadaan 
gudang penyimpanan dan kendaraan pengangkut bahan PMT-P. Fasilitas gudang penyimpanan yang khusus untuk program PMT$\mathrm{P}$ di dinas kesehatan belum ada. Bahan PMT-P ketika sudah ada di dinas kesehatan langsung dibagikan ke puskesmas masing-masing sejumlah alokasi balita sasaran yang telah ditentukan. Jikapun ada penyimpanan di dinas kesehatan, biasanya digabungkan dengan gudang arsip. Demikian halnya untuk penyimpanan di puskesmas, gudang penyimpanan bahan PMT-P digabungkan dengan gudang arsip.

Sementara alat transportasi untuk mengangkut bahan PMT-P dari dinas kesehatan ke puskesmas atau dari puskesmas ke ibu balita sasaran juga tidak tersedia secara khusus. Berdasarkan informasi yang sudah dihimpun, bahan PMT-P dari dinas ke puskesmas diangkut menggunakan mobil puskesmas keliling, atau mobil sewa bak terbuka, bahkan ada juga puskesmas yang menggunakan ambulan untuk mengangkut bahan PMT-P. Sedangkan pengangkutan bahan PMT-P dari puskesmas ke ibu balita sasaran, dilakukan oleh bidan desa dengan menggunakan motor, untuk kemudian disimpan terlebih dahulu di polindes sebelum dibagikan ke ibu balita sasaran.

\section{$\underline{\text { Bahan PMT-P }}$}

Bahan paket program PMT-P baik di Kabupaten Tuban berupa makanan kemasan. Makanan kemasan PMT-P di Kabupaten Tuban berupa susu Pan Enteral 90 sachet per anak yang dikonsumsi selama 90 hari. Paket program PMT-P sudah sesuai dengan pengadaan yang dilakukan oleh dinas kesehatan. Paket PMT-P tidak ada yang mengalami kerusakan, tercecer ataupun tersisa, baik di dinas kesehatan, puskesmas ataupun di polindes/rumah bidan desa. Hal ini dapat dijustifikasi bahwa bahan paket PMT-P sudah sesuai dengan peruntukannya untuk tambahan makanan balita baik dilihat dari segi jenis, jumlah dan mutunya.

\section{Pendanaan}

Pendanaan sangat penting kaitannya dengan pelaksanaan program PMT-P. Namun, seringkali dana yang tersedia untuk program PMT-P tidak bisa mengkover semua balita gizi buruk dan gizi kurang yang ada. Demikian halnya, pendanaan untuk program PMT-P di Kabupaten Tuban. Untuk itu, alokasi balita sasaran diprioritaskan kepada balita gizi buruk dan gizi kurang dari keluarga miskin. Prioritas alokasi balita sasaran khusus untuk keluarga miskin dianggap penting karena mengingat bahwa masalah gizi di Kabupaten Tuban tidak semata-mata karena faktor kemiskinan, banyak keluarga mampu yang memiliki anak kurang gizi.

\section{Aspek Proses}

\section{Persiapan}

Persiapan merupakan langkah yang juga penting dilakukan sebelum program PMT-P dilaksanakan. Persiapan yang perlu dilakukan dalam program PMT-P diantaranya adalah pendataan balita sasaran, sosialisasi dan rapat koordinasi antara para pelaksana program PMTP. Proses pendataan balita sasaran sudah sesuai dengan prosedur yang telah ditetapkan. Terbatasnya dana dari dinas kesehatan mengakibatkan tidak semua balita gizi kurang masuk dalam kriteria balita sasaran. Hanya balita yang memiliki status gizi sangat kurang dan kurus serta berasal dari keluarga miskin yang menjadi prioritas balita sasaran.

Sementara itu, selain pendataan balita sasaran, sosialisasi dan rapat koordinasi program PMT-P merupakan aspek persiapan yang juga penting untuk dilakukan agar pelaksanaan program PMT-P tidak tumpang tindih dengan program lainnya dan untuk menyamakan persepsi dalam pelaksanaan program PMT-P baik di tingkat dinas kesehatan maupun puskesmas. Sosialisasi program dan rapat koordinasi program PMT-P di Kabupaten Tuban dilakukan di awal tahun berjalan kepada seluruh kepala puskesmas dan petugas gizi. Sosialisasi dan rapat koordinasi program PMT-P sudah berjalan dengan baik di Kabupaten Tuban. Sosialisasi dan koordinasi yang baik dalam program PMT-P akan dapat meningkatkan kelancaran pelaksanaan program PMT-P.

\section{Pelaksanaan}

Pelaksanaan program PMT-P merupakan aspek paling penting dalam tahapan-tahapan program PMT-P. Pelakasanaan program PMT-P yang dimaksud dalam penelitian ini meliputi penyimpanan bahan PMT-P, pengangkutan bahan PMT-P, dan pendistribusian bahan PMT$\mathrm{P}$ ke balita sasaran. Penyimpanan bahan PMT-P 
merupakan bagian dari pelaksanaan program PMT-P yang perlu diperhatikan. Dalam menjaga kualitas bahan PMT-P, tempat atau gudang penyimpanan harus dihindarkan dari adanya binatang pengganggu seperti tikus, kecoa, dan binatang lainnya. Namun, penyimpanan bahan PMT-P tidak lagi dilakukan oeleh Dinas Kesehatan Kabupaten Tuban. Setelah bahan PMT-P tiba di dinas kesehatan dari rekanan, pihak puskesmas langsung mengambil bahan PMT-P tersebut. Demikian halnya dengan puskesmas, begitu bahan PMT-P tiba di puskesmas, bidan desa langsung mengambil bahan PMT-P untuk selanjutnya disimpan di rumah bidan desa atau di polindes sebelum dibagikan ke ibu balita sasaran

Sementara untuk pengangkutan bahan PMT-P, standar keamanan kurang diperhatikan. Padahal standar keamanan ini akan mempengaruhi kualitas bahan PMT-P. Proses pengangkutan bahan PMT-P harus terhindar dari bahan-bahan yang dapat merusak kualitas bahan PMT-P seperti cairan, tumpukan benda berat atau benda tajam. Dalam pengangkutan bahan PMT-P yang perlu diperhatikan adalah pemilihan jenis kendaraan untuk mengangkut. Minimnya fasilitas pengangkutan seperti kendaraan khusus untuk mengangkut PMT-P sebenarnya dapat menghambat pelaksanaan program PMTP. Pengangkutan bahan PMT-P di Kabupaten Tuban tidak menggunakan kendaraan khusus. Kendaraan yang digunakan adalah mobil puskesmas keliling atau mobil sewa bak terbuka. Namun, keterbatasan ini tidak lantas dijadikan hambatan yang berarti di dinas kesehatan Kabupaten Tuban. Hal yang terpenting adalah bahan PMT-P dapat diangkut hingga sampai kepadaibu balita sasaran.

Selanjutnya untuk pendistribusian bahan PMT ke sasaran, Dinas Kesehatan Kabupaten Tuban tidak mengantarkan bahan PMT-P ke puskesmas. Sebaliknya, pihak puskesmas yang mengambil bahan PMT-P ke dinas kesehatan. Serah terima bahan PMT-P dilakukan oleh pihak dinas kesehatan dengan tenaga pelaksana gizi puskesmas berdasar jadwal yang telah diberitahukan terlebih dahulu oleh pihak dinas kesehatan. Sementara ketika bahan PMT-P sudah diterima di puskesmas, bahan PMT-P langsung diambil oleh bidan desa masing-masing tanpa mengalami proses penyimpanan terlebih dahulu di puskesmas.
Jikapun ada penyimpanan hanya sebagian kecil saja puskesmas yang mengadakan hal tersebut.

Pendistribusian bahan PMT-P kepada ibu balita sasaran dilakukan secara bertahap. Jadwal pendistribusian bahan PMT-P menggunakan hari lain diluar jadwal posyandu. Jadwal pendistribusian harus sudah diberitahukan terlebih dahulu kepada ibu balita sasaran. Hal ini untuk menghindari kecemburuan sosial karena tidak semua balita yang datang ke posyandu mendapatkan PMT-P. Pendistribusian bahan PMT-P sudah berjalan dengan baik. Namun, kendala terjadi apabila ibu-ibu balita sasaran tidak datang ke polindes atau bidan desa untuk mengambil bahan PMT-P dan atau menimbang balita mereka. Alasan mereka tidak datang adalah karena bahan PMTP masih ada atau balita sudah bosan memakan paket PMT-P. Dalam kondisi ini, peran kader sangat penting untuk mengantarkan bahan PMT-P ke rumah ibu balita sasaran.

\section{Pemantauan}

Pemantauan pelaksanaan program PMT-P dapat dilakukan dengan mengevaluasi tentang bagaimana pelaksanaannya, apakah sudah terdistribusi ataukah belum dan bagaimana perkembangan pertumbuhan balita serta bagaimana daya terima balita sasaran terhadap bahan PMT-P. Pemantauan terhadap pelaksanaan program PMT-P seharusnya dilakukan oleh pihak dinas kesehatan. Namun, dinas kesehatan justru menyerahkan pelaksanaan sepenuhnya kepada pihak puskesmas. Dinas Kesehatan mengevaluasi pelaksanaan program PMT-P berdasarkan laporan dari puskesmas setelah program PMT-P berakhir. Pemantauan program PMT-P yang dimaksud dalam penelitian ini meliputi penimbangan berat badan balita sasaran, dan pencatatan dan pelaporan hasil penimbangan ke dinas kesehatan.

Penimbangan berat badan balita sasaran program PMT-P dilakukan setiap minggu sekali pada waktu pengambilan bahan PMT-P ke polindes, namun ada juga puskesmas yang melakukan penimbangan setiap dua minggu sekali pada waktu pengambilan bahan PMT-P ke polindes. Apabila ibu balita sasaran dan balitanya tidak datang pada waktu pengambilan bahan PMT-P, penimbangan dilakukan satu bulan sekali, pada waktu jadwal posyandu 
Sementara itu, selain penimbangan balita sasaran, pencatatan dan pelaporan juga merupakan kegiatan penting yang harus dilaksanakan oleh pelaksana program terutama petugas pelaksana gizi puskesmas. Hal ini untuk mengetahui dan melaporkan bagaimana perkembangan atau perubahan berat badan balita sebelum dan sesudah program PMT-P. Pencatatan berat badan balita sasaran dilakukan pada waktu pendistribusian PMT-P ke sasaran, yaitu pada waktu ibu dan balita datang bersama balita untuk mengambil bahan PMT-P dan menimbangkan balitanya. Sementara pelaporan dilakukan setelah program PMT-P berakhir dan tidak ada pemantauan selama program berlangsung. Seharusnya pelaporan dilakukan setiap satu bulan sekali, sehingga dapat dijadikan sebagai bahan evaluasi dari pelaksanaan program PMT-P yang dilaksanakan mulai bulan pertama, bulan kedua, dan bulan ketiga. Minimnya pemantauan selama program berlangsung dapat menyebabkan lemahnya kontrol dalam pelaksanaan program PMT-P. Hal ini dapat menjadi penghambat sehingga pelaksanaan program PMT-P tidak berjalan secara maksimal sesuai dengan tujuan yang diharapkan.

\section{Aspek Output}

\section{Ketepatan sasaran.}

Ketepatan sasaran dalam penelitian ini adalah ketepatan umur sasaran dan ketepatan penerima PMT-P. Berdasarkan sebaran umur, semua sasaran program PMT-P berada dalam rentang umur 6-59 bulan. Hal ini mengindikasikan bahwa pemberian PMT-P sudah sesuai dengan umur sasaran dalam aturan yang ditetapkan dalam pedoman atau juknis dinas kesehatan.

Sementara untuk ketepatan penerima PMT-P sering tidak sesuai dengan sasaran program yang telah ditetapkan. Hal ini karena balita sasaran program PMT-P terkadang menolak PMT-P yang diberikan, bahkan ibu balita terkadang memberikan kepada tetangga mereka atau balita lain yang tidak termasuk kriteria program. Dalam mensiasati masalah ini dan supaya bahan PMT-P yang diberikan tidak mubazir atau terbuang, petugas pelaksana gizi puskesmas atas persetujuan dinas kesehatan mengambil langkah dengan cara mengganti balita sasaran program PMT-P dengan balita lain yang tidak tercover program, namun memiliki kriteria sebagai sasaran program PMT-P.

Penolakan balita terhadap PMT-P dan penggantian balita sasaran dengan balita lain merupakan beberapa kendala yang terjadi dilapangan. Hal ini mengakibatkan ketidaktepatannya sasaran program PMT-P, balita yang seharusnya dapat PMT-P menjadi tidak dapat, sebaliknya balita yang seharusnya tidak dapat PMT-P jadi mendapatkan PMT-P karena harus menggantikan posisi menjadi balita sasaran. Terbatasnya anggaran menyebabkan balita yang menolak PMT-P tidak mendapatkan PMT-P pengganti. Hal ini apabila dibiarkan akan menyebabkan balita tersebut akan bertambah buruk status gizinya, apalagi ketika ibu balita kurang perhatian terhadap kondisi gizi anaknya. Dalam mengatasi masalah ini seharusnya pada tahap perencanaan, menu PMT-P yang diberikan disesuaikan dengan preferensi balita, dan lebih memvariasikan makanan PMT-P untuk menghindari kebosanan balita terhadap bahan PMT-P.

\section{Kenaikan beratbadan balita sasaran.}

Kenaikan berat badan balita merupakan salah satu indikator output untuk melihat keberhasilan pelaksanaan program PMT-P. Dari Tabel 2 dapat dilihat bahwa pemberian PMT-P selama 90 hari pada balita dapat meningkatkan berat badan balita rata-rata sebesar $1 \mathrm{~kg}$ dari 8.3 $\mathrm{kg}$ menjadi $9.3 \mathrm{~kg}$. Terdapatnya peningkatan berat badan balita sasaran program PMT-P menunjukkan bahwa program PMT-P pada balita di Kabupaten Tuban memberikan dampak positif untuk kenaikan berat badan balita sasaran. Hasil penelitian ini sejalan dengan penelitian yang dilakukan oleh Supadmi dkk (2008) tentang pengaruh PMT-P pada balita Kurang Energi Protein (KEP) di Magelang yang menemukan bahwa terjadi peningkatan berat badan rata-rata sebesar 700 gram dari $8.5 \mathrm{~kg}$ menjadi $9.2 \mathrm{~kg}$ setelah program PMT-P.

Tabel 2. Berat Badan Balita Sebelum dan Sesudah Program PMT-P

\begin{tabular}{lrr}
\hline \multirow{2}{*}{ Keterangan } & \multicolumn{2}{c}{ Kab. Tuban } \\
\cline { 2 - 3 } & Sebelum & \multicolumn{1}{c}{ Sesudah } \\
\hline $\mathrm{n}$ & 26 & 26 \\
\hline Min & 5.7 & 6.5 \\
\hline Max & 12 & 13 \\
\hline Mean & 8.3 & 9.3 \\
\hline Sd & 1.83 & 1.93 \\
\hline
\end{tabular}

Sumber: Data Primer, diolah 
Sementara berdasarkan hasil uji statistik dalam Tabel 3 menunjukkan adanya perbedaan berat badan yang bermakna $(p<0.05)$ antara sebelum dan sesudah program PMT-P selama 90 hari. Hal ini menunjukkan bahwa program PMT$\mathrm{P}$ dapat meningkatkan secara efektif terhadap berat badan balita sasaran program PMT-P.

Tabel 3. Perbedaan Berat Badan Balita Sebelum dan Sesudah Program PMT-P Berdasarkan Hasil Uji Paired T Test

\begin{tabular}{|c|c|c|c|c|}
\hline \multirow[t]{2}{*}{ Variabel } & \multirow[t]{2}{*}{$\mathrm{n}$} & \multicolumn{3}{|c|}{ Nilai } \\
\hline & & df & $\mathrm{t}$ & p-value \\
\hline BB sebelum dan & & & - & \\
\hline sesudah PMT-P & 26 & 25 & 7.117 & $0.000 *$ \\
\hline
\end{tabular}

Sumber: Data Primer, diolah

Pemberian PMT-P merupakan tambahan makanan utama balita sasaran dan bukan merupakan makanan pengganti makanan sehari-hari balita sasaran. Adanya kenaikan berat badan tidak hanya karena pemberian PMT$P$ saja, namun ada faktor lain yang diduga juga turut meningkatkan berat badan balita sasaran program PMT-P, seperti konsumsi makanan utama balita (Supadmi dkk, 2008) dan konsumsi snack atau makanan selingan balita.

\section{KESIMPULAN}

Dari uraian diatas, dapat disimpulkan bahwa dari aspek input, ketersediaan SDM sudah memadai dari kualitas dan kuantitasnya, bahan PMT-P juga sudah memadai, namun untuk petunjuk pelaksanaan belum terdistribusikan dengan baik, sarana prasarana dan pendanaan juga masih kurang. Sementara dari segi proses, proses persiapan seperti pendataan balita dan sosialisasi serta rapat koordinasi sudah berjalan dengan baik, demikian halnya dengan proses pendistribusian paket PMT-P. Namun, untuk proses penyimpanan dan pengangkutan masih kurang memadai. Sedangkan untuk proses pemantauan, penimbangan sudah dilakukan dengan baik, akan tetapi untuk monitoring selama program PMT-P berlangsung masih kurang. Dari segi output, masih terdapat ketidaktepatan sasaran, namun, terdapat kenaikan berat badan balita sasaran yang signifikan setelah program berakhir.

\section{DAFTAR PUSTAKA}

-. 2009. Undang-Undang Republik Indonesia Nomor 36 Tahun 2009 Tentang Kesehatan. Jakarta

Adiyasa dkk. 2010. Evaluasi Program Pemberian MP-ASI bubuk instan dan biskuit di Kota Mataram, Kabupaten Lombok Barat, Lombok Timur, dan Bengkulu Utara Tahun 2007. Jurnal Gizi Klinik Indonesia, Vol.6. No.3, Maret:145-155

Dinas Kesehatan Provinsi Jawa Timur. 2012. Profil Kesehatan Jawa Timur Tahun 2012. Surabaya: Dinkesprov Jatim

Kementerian Kesehatan Republik Indonesia. 2008a. Riset Kesehatan Dasar 2007. Jakarta : Badan litbangkes Kemenkes, RI

Kementerian Kesehatan Republik Indonesia. 2008b. Riset Kesehatan Dasar dalam Angka Provinsi Jawa Timur Tahun 2007. Jakarta : Balitbangkes, Kemenkes RI

Kementerian Kesehatan Republik Indonesia. 2010. Laporan Riset Kesehatan Dasar 2010. Jakarta: Badan litbangkes Kemenkes RI

Kementerian Kesehatan Republik Indonesia. 2011. Panduan Penyelenggaraan Pemberian Makanan Tambahan Pemulihan bagi Balita Gizi Kurang. Jakarta : Kementerian Kesehatan RI

Kementerian Kesehatan Republik Indonesia. 2013a. Laporan Riset Kesehatan Dasar 2013. Jakarta: Badan litbangkes Kemenkes RI

Kementerian Kesehatan Republik Indonesia. 2013b. Riset Kesehatan Dasar dalam Angka Provinsi Jawa Timur Tahun 2013. Jakarta : Balitbangkes, Kemenkes RI

Lubis dkk. 2012. Analisis Implementasi Program Penanggulangan Gizi Buruk pada Anak Balita di Wilayah Kerja Puskesmas Medan Labuhan, Kota Medan Tahun 2008. Penel Gizi Makan35(1):70-77 
Rochyani dkk. 2007. Pengaruh Pemberian MPASI Program dan MP-ASI Komersial terhadap Pertumbuhan Bayi Usia 6-11 Bulan di Kabupaten Kampar. Jurnal Gizi Klinik Indonesia Vol.3,No.3, Maret :106114

Sulistyaningsih R. 2012. Evaluasi Program Pemberian Makanan Pendamping Air Susu Ibu (MP-ASI) Lokal Terhadap Perbaikan Status Gizi Balita di Kelurahan Saigon dan Parit Mayor Kecamatan $\mathrm{P}$ o n t i a a k T i m u r. http://download.portalgaruda.org/arti cle.php? article $=111576 \& \mathrm{val}=5161$, diakses tanggal 6 Oktober 2014
Supadmi dkk. 2008. Pengaruh Pemberian Makanan Tambahan pada Balita Kurang Energi Protein (KEP) Pengunjung Balai Penelitian dan Pengembangan Gangguan Akibat Kekurangan Yodium (BPP GAKY) Magelang. PGM31(2):59-66 